\title{
ARTIKELEN
}

\section{Institutioneel misbruik en geweld uit het verleden}

\author{
Een vergelijking van twee herstelgerichte responsmodellen in \\ België
}

Ivo Aertsen \& Martien Schotsmans

\section{Inleiding}

Gedurende de voorbije decennia is wereldwijd - vaak op dramatische wijze - aandacht ontstaan voor diverse vormen van geweld en misbruik zoals die zich in het verleden voorgedaan hebben binnen bepaalde institutionele contexten. De instelling die daarbij het meest in het oog sprong, was zonder enige twijfel de roomskatholieke kerk (hierna: de kerk), maar gaandeweg kwam het fenomeen ook aan de oppervlakte in andere religieuze middens en sectoren, zoals de zorgsector, de sportwereld, de cultuurwereld en de media. Uiteraard doen vormen van geweld (fysiek, psychologisch, seksueel) zich vandaag nog steeds voor in deze sectoren, maar in deze bijdrage willen we ingaan op de wijze waarop instituties antwoorden ontwikkeld hebben om te reageren op geweld uit het verleden, dat vaak strafrechtelijk niet meer kan worden behandeld. We beschrijven, analyseren en vergelijken daarbij twee responsmodellen die in België gehanteerd werden/ worden, gaan na waar de herstelrechtelijke insteek te vinden is en welke lessen daaruit te trekken zijn voor de verdere ontwikkelingen van het herstelrecht. Het ene model werd specifiek voor historisch misbruik in de kerk ontwikkeld op federaal niveau, het andere kwam tot stand op het niveau van de Vlaamse Gemeenschap en is gericht op misbruik in het verleden in diverse institutionele contexten.

Beide auteurs zijn in de praktijk actief bij deze initiatieven betrokken (geweest): Ivo Aertsen was aangesteld als expert bij de federale parlementaire Bijzondere Commissie (zie punt 2.2 hieronder) in 2010-2011 en was vervolgens gedurende vier jaar lid van de Permanente Arbitragekamer inzake seksueel misbruik in de kerk; Martien Schotsmans was als arbiter betrokken bij twee dossiers inzake seksueel misbruik in de kerk en is sinds april 2019 coördinator van de Vlaamse Commissie voor Erkenning en Bemiddeling inzake misbruik en geweld uit het verleden. Dit artikel is in grote mate tot stand gekomen op basis van deze praktijkervaringen. Beide auteurs schrijven deze bijdrage uit eigen naam. 


\section{Korte historiek en overzicht}

\subsection{Wat voorafging}

Onder leiding van priester Rik Devillé voerde de Werkgroep Mensenrechten in de Kerk in België sinds de jaren negentig een jarenlange strijd voor de erkenning van de slachtoffers van seksueel en ander misbruik binnen de kerk (Devillé, 2019). Eind jaren negentig nam de kerk hierrond schoorvoetend enkele initiatieven, maar het was pas na het schandaal rond bisschop Vangheluwe in 2010 dat er een daadwerkelijke aanpak werd uitgewerkt, eerst door de Commissie Adriaenssens binnen de kerk, vervolgens door het Belgische parlement. Het Vlaamse parlement volgde later met initiatieven rond misbruik in andere sectoren.

\section{- Commissie-Halsberghe}

In 2001 stelden de kerkelijke overheden een 'Commissie voor de behandeling van klachten wegens seksueel misbruik in een pastorale relatie' in, voorgezeten door oud-magistraat Godelieve Halsberghe. Deze had als opdracht klachten van slachtoffers in ontvangst te nemen, de slachtoffers te horen en adviezen uit te brengen over eventuele maatregelen. Tussen mevrouw Halsberghe en de kerk ontstond op een bepaald ogenblik onenigheid over het al dan niet toekennen van financiële vergoedingen aan de slachtoffers. De opdracht van de commissie liep af op 25 februari 2009. Ze had in haar achtjarig bestaan 33 dossiers behandeld. ${ }^{1}$

\section{- Commissie-Adriaenssens}

Begin 2010 bliezen de Belgische bisschoppen en de hogere oversten van de religieuze ordes en congregaties de hogervermelde 'Commissie voor de behandeling van klachten wegens seksueel misbruik in een pastorale relatie' nieuw leven in, onder voorzitterschap van psychiater Peter Adriaenssens. De opdracht van deze commissie bleef dezelfde, maar haar werkwijze was - althans in concept - eerder geïnspireerd door de principes van een waarheids- en verzoeningscommissie en derhalve herstelrechtelijk relevant. In april 2010 barstte het schandaal los rond bisschop Vangheluwe van Brugge wegens jarenlang misbruik van een neef. Dit misbruik door een hooggeplaatste binnen de kerk en het feit dat de kerk hier jarenlang weinig of niets mee had gedaan, ondanks aandringen van het slachtoffer, leidden tot grote publieke verontwaardiging. Monseigneur Vangheluwe trad op 23 april 2010 af. Op enkele maanden tijd werd de commissie-Adriaenssens door 475 slachtoffers gecontacteerd.

Op 24 juni 2010 werden evenwel alle dossiers op verzoek van onderzoeksrechter De Troy in beslag genomen tijdens de zogenaamde 'Operatie Kelk', waarna de commissie-Adriaenssens zich genoodzaakt zag haar activiteiten te staken. De gerechtelijke instanties wilden onderzoeken of er in deze en andere dossiers misschien sprake was van niet-verjaarde feiten die werden toegedekt en of er sprake was van schuldig verzuim. Deze en andere inbeslagnames gaven aanleiding tot een gerechtelijke procedureslag die tot op heden voortduurt. Desalniettemin

1 Eindverslag van het Wetenschappelijk Comité van het Centrum voor Arbitrage inzake Seksueel Misbruik, Parl. St., Kamer, 2016-2017, nr. 0767/004 (10 april 2017). 
slaagde de commissie-Adriaenssens er in september 2010 nog in een aantal (schrijnende) getuigenissen in een onafgewerkt rapport te verwerken (Adriaenssens, 2010).

Het federaal parket vorderde op 28 april 2016 dat het verval van de strafvordering zou worden vastgesteld, wegens eerdere veroordelingen, overlijden van de verdachten of verjaring van de feiten, op één dossier na waarin nog een onderzoek loopt tegen een pater die in Brazilië verblijft. Hierop vroegen de advocaten van de slachtoffers bijkomende onderzoeksmaatregelen, welke nog lopende zijn. ${ }^{2}$

\subsection{Initiatieven op het federale niveau}

$\mathrm{Na}$ het gerechtelijke optreden en de stopzetting van de werkzaamheden van de commissie-Adriaenssens werd door het Belgische federale parlement op 28 oktober 2010 een 'Bijzondere Commissie betreffende de behandeling van seksueel misbruik en feiten van pedofilie binnen een gezagsrelatie, inzonderheid binnen de Kerk' opgericht. Deze onderzoekscommissie diende na te gaan hoe door de rooms-katholieke kerk en de Staat werd omgegaan met feiten van seksueel misbruik uit het verleden, hoe slachtoffers werden opgevangen, hoe wetgevende en andere voorstellen konden geformuleerd worden en of eigen oplossingen konden aangereikt worden. De commissie publiceerde haar eindverslag in maart 2011, met inbegrip van 69 aanbevelingen waaronder de oprichting van een Centrum voor Arbitrage inzake seksueel misbruik. ${ }^{3}$

Tot 31 oktober 2012 konden slachtoffers bij dit centrum een dossier indienen, voor zover het ging om seksueel misbruik door geestelijken in de kerk waarvoor wegens verjaring geen strafrechtelijke actie meer kon ondernomen worden. Er werden in totaal 628 dossiers ontvangen, die behandeld werden over een periode van bijna vier jaar. De procedure, zoals die uitgetekend werd in een proces van onderhandeling tussen vertegenwoordigers van het parlement en de kerk, bestond uit twee fasen: de 'verzoeningsfase' voor een Permanente Arbitragekamer (PAK) bestaande uit zeven leden en de eigenlijke 'arbitragefase'. Voor dit laatste werd een formeel systeem van scheidsgerecht ingesteld, waarvoor partijen (slachtoffer en kerk) een beroep konden doen op telkens drie onafhankelijke arbiters uit een lijst van daartoe erkende personen. Van de 628 dossiers, ingediend bij het Centrum voor Arbitrage, werden er 507 afgesloten met een financiële tegemoetkoming. Van al deze dossiers gingen er slechts drie naar de tweede fase van de eigenlijke, formele arbitrage.

Het overgrote deel van de dossiers werd dus afgehandeld in de fase van de 'verzoening', waar de slachtoffers individueel door twee of drie leden van de Permanente Arbitragekamer in wekelijkse zittingen werden gehoord en in gesprek werden gebracht met de aanwezige vertegenwoordigers van de kerk. Om deze verte-

2 Persbericht van het federaal parket. Onderzoek naar seksueel misbruik en schuldig verzuim in de Kerk. De eindvordering in het dossier 'Kelk' van het federaal parket (9 november 2015).

3 Bijzondere Commissie betreffende de behandeling van seksueel misbruik en feiten van pedofilie binnen een gezagsrelatie, inzonderheid binnen de Kerk (2011). De behandeling van seksueel misbruik en feiten van pedofilie binnen een gezagsrelatie, inzonderheid binnen de Kerk. Verslag namens de bijzondere commissie uitgebracht door S. De Wit, M.-C. Marghem, R. Terwingen \& R. Landuyt, Parl. St., Kamer, 2010-2011, nr. 0520/002 (31 maart 2011). 
genwoordiging door de kerk - en de juridische en financiële afhandeling mogelijk te maken, werd door de Belgische bisschoppen en religieuze congregaties en ordes een Stichting van Openbaar Nut opgericht, onder de naam 'Dignity'. Aan de zittingen van de Permanente Arbitragekamer werd deelgenomen door één of twee vaste vertegenwoordigers van deze stichting, bijgestaan door een advocaat wanneer het slachtoffer zich eveneens door een advocaat liet vergezellen. Slachtoffers konden zich daarnaast tijdens de zitting laten bijstaan door een familielid, hulpverlener of ander vertrouwenspersoon.

De behandeling in deze verzoeningsfase voor de Permanente Arbitragekamer bestond uit elementen van hulpverlening, bemiddeling en adviesverlening, dit laatste met betrekking tot een mogelijk bedrag van financiële tegemoetkoming. De Permanente Arbitragekamer - achteraf bekeken een onnauwkeurige benaming - streefde een 'integrale benadering' na, waarbij - meer dan de financiële schadevergoeding - het bieden van erkenning aan het slachtoffer en het faciliteren van een gesprek met de kerk centraal stonden. ${ }^{4}$ Meer informatie over de samenstelling en de werkwijze van de PAK is opgenomen in paragraaf 3 van deze bijdrage. Naast het Centrum voor Arbitrage werden op initiatief van de kerk in 2012 ook tien interne 'opvangpunten' geïnstalleerd binnen de bisdommen en congregaties (De bisschoppen en hogere oversten van België, 2019). Slachtoffers kunnen daar (nog steeds) terecht voor erkenning, hulpverlening, bemiddeling en financiële tegemoetkoming, ook voor recente feiten. In de periode 2012-2017 werden in de tien opvangpunten in totaal 426 meldingen gedaan en werd er in totaal $€ 1.580 .001$ uitbetaald (een gemiddelde van $€ 3.708$, met dien verstande dat niet alle slachtoffers vragende partij zijn voor een financiële tegemoetkoming). Deze bedragen, toegekend aan slachtoffers die zich rechtstreeks tot de meldpunten wendden, komen bovenop het totaal aan bedragen die via het Centrum voor Arbitrage werden toegekend aan de slachtoffers die zich tot die instantie hadden gericht. Binnen de kerk werd ook een Raad van Toezicht samengesteld, bestaande uit een aantal deskundigen die de bisschoppen en oversten adviseren inzake de opvolging van plegers van seksueel misbruik.

\subsection{Initiatieven op het Vlaamse niveau}

In 2012 en 2013 traden meerdere slachtoffers naar buiten die publiek getuigden over hun ervaringen als kind of jongere met diverse vormen van geweld en misbruik door steunfiguren in jeugd- en onderwijsinstellingen (binnen en buiten de kerk) en in het kader van therapeutische relaties. Daarop werd door de Vlaamse regering, verantwoordelijk voor deze sector, een reeks beleidsinitiatieven genomen, te beginnen met de installatie van een 'expertenpanel historisch misbruik in jeugd- en onderwijsinstellingen in Vlaanderen' in mei 2013, resulterend in een aantal aanbevelingen (De Blauwe, 2019). ${ }^{5}$ Daarnaast vond een beperkt kwalitatief

4 Eindverslag van het Wetenschappelijk Comité van het Centrum voor Arbitrage inzake Seksueel Misbruik, Parl. St., Kamer, 2016-2017, nr. 0767/004 (10 april 2017); zie ook Verhoeven \& Aertsen, 2019.

5 Ondubbelzinnig kiezen voor erkenning. Historisch geweld en misbruik in jeugd- en onderwijsinstellingen in Vlaanderen. Analyse, duiding en beleidsaanbevelingen, Eindrapport expertenpanel, 9 december 2013. 
onderzoek plaats naar slachtofferervaringen en noden van mensen die contact hadden opgenomen met de telefonische hulplijn voor slachtoffers van geweld '1712' (Roevens \& Aertsen, 2014).

Tegelijkertijd kwamen in 2012 een aantal getuigenissen rond misbruik van volwassenen in therapeutische relaties aan het licht. Om meer zicht te krijgen op de omvang van het probleem zette de Vlaamse overheid een experimenteel project op waarbij slachtoffers werden opgeroepen om zich te melden via de hulplijn 1712, waar hulpverleners van de Centra voor Algemeen Welzijnswerk (CAW) en de Vertrouwenscentra Kindermishandeling hen te woord stonden. De oproep kreeg gehoor en heel wat slachtoffers meldden zich. ${ }^{6}$

Daarop werd in april 2014 door het Vlaamse parlement een resolutie aangenomen over 'de erkenning van slachtoffers van historisch geweld en misbruik in jeugd- en onderwijsinstellingen in Vlaanderen en het omgaan met geweld in het algemeen. ${ }^{7}$ In deze resolutie sprak het parlement namens de samenleving zijn verontschuldigingen uit ten aanzien van deze slachtoffergroep. Eén van de aanbevelingen betrof de organisatie van lotgenotencontacten in elke provincie onder leiding van een professionele coach, omkaderd door het Steunpunt Algemeen Welzijnswerk. Tevens werd, bij wijze van publieke erkenning, overgegaan tot de organisatie van een tentoonstelling over het thema, 'Pleisterplekken', die van 22 december 2014 tot en met 15 februari 2015 in het museum Dr. Guislain in Gent liep.

Ten slotte werd een tijdelijke, onafhankelijke 'Erkennings- en bemiddelingscommissie voor slachtoffers van historisch misbruik' opgericht die op 1 december 2014 van start ging en in nauwe samenwerking met de Vlaamse hulplijn 1712 functioneerde. Deze commissie was bevoegd voor feiten van fysiek, seksueel of psychologisch geweld en verwaarlozing die tussen 1930 en 1990 plaatsvonden. Het betrof (betreft) feiten gepleegd in zeer uiteenlopende contexten van nietfamiliale afhankelijkheidsrelaties in jeugd- of onderwijsinstellingen, waaronder weeshuizen en pleeggezinnen, scholen en internaten, psychiatrische en jeugdhulpvoorzieningen, jeugdorganisaties, sportkampen, enzovoort, en dit ongeacht de beroepsgroep of leeftijd van zowel (vermeende) pleger als slachtoffer. De leden van de commissie waren personen met ervaring in slachtofferzorg, bemiddeling en andere relevante sectoren. De commissie richtte zich vooral op het bieden van erkenning en ondersteuning, dialoog en bemiddeling (met de instelling waar de feiten plaatsvonden). De commissie zelf was niet bevoegd om een financiële tegemoetkoming toe te kennen, maar bemiddelde wel in dossiers waarin een financiële tegemoetkoming van kerkelijke instellingen werd gevraagd.

'De erkennings- en bemiddelingscommissie' zou zes maanden actief zijn, maar omdat de respons aanvankelijk beperkt bleef, werd de duur verlengd tot eind december 2015. Van de zestig oproepen over historisch misbruik die binnenkwamen via 1712, klopten uiteindelijk negentien slachtoffers aan bij de commissie en

6 Experimenteel project 1712. Aanpak misbruik van volwassenen in gezagsrelaties. 01.01.2013-31.10.2013. Werkingsverslag en beleidsaanbevelingen.

7 Resolutie betreffende de erkenning van slachtoffers van historisch geweld en misbruik in jeugden onderwijsinstellingen in Vlaanderen en het omgaan met geweld in het algemeen: http:// docs.vlaamsparlement.be/pfile?id=1037652 (stuk 2475 (2013-2014) - Nr. 3, ingediend op 2 april 2014 en aangenomen door de plenaire vergadering). 
uiteindelijk werden er veertien dossiers opgestart. De commissie schreef deze relatief beperkte respons toe aan het feit dat het initiatief slechts gedurende korte tijd en met te weinig middelen aan het ruime publiek kenbaar kon gemaakt worden. Verder verliep de toegang tot de tijdelijke commissie altijd gefaseerd: aanmelders moesten noodzakelijkerwijze via het centrale meldpunt 1712 passeren en, indien hulp gewenst was voor het invullen van het aanvraagformulier, via het CAW. Verder hanteerde de commissie ook bepaalde uitsluitingscriteria, waardoor ze onder meer aanvragen die al behandeld werden door het Centrum voor Arbitrage inzake Seksueel Misbruik in de Kerk onontvankelijk verklaarde. ${ }^{8}$

In haar eindrapport adviseerde de commissie een permanent, onafhankelijk overkoepelend aanspreekpunt voor slachtoffers op te richten. ${ }^{9}$

Mede ingegeven door de bekendmaking van nieuwe feiten van grensoverschrijdend gedrag in de cultuur-, media- en sportwereld in 2017, werd besloten deze commissie een permanent karakter te verlenen. Deze laatste getuigenissen gaven aanleiding tot de oprichting van een Bijzondere Commissie 'Grensoverschrijdend gedrag' in het Vlaamse parlement, die zich ging buigen over de problematiek in de diverse maatschappelijke domeinen. Hierop volgde andermaal een resolutie van het Vlaamse parlement, met een aantal aanbevelingen. ${ }^{10} \mathrm{Als}$ gevolg hiervan werd op 13 juli 2018 het decreet goedgekeurd 'houdende de erkennings- en bemiddelingscommissie voor slachtoffers van historisch misbruik'. ${ }^{11}$ Het toepassingsgebied van deze commissie werd sterk uitgebreid in vergelijking met dat van de tijdelijke commissie. Net zoals voorheen is de commissie bevoegd voor feiten van seksueel, fysiek of psychisch geweld en verwaarlozing, ongeacht de hoedanigheid of leeftijd van (vermeende) pleger of slachtoffer. De temporele bevoegdheid werd evenwel uitgebreid tot feiten die op het ogenblik van de melding minstens tien jaar geleden gebeurd zijn. Verder is er geen beperking meer tot feiten die zich in jeugd- en onderwijsinstellingen hebben voorgedaan.

De opdrachten van de commissie betreffen individuele opvang en het bieden van erkenning aan de slachtoffers, hun de mogelijkheid bieden om de (vermeende) pleger(s) van het misbruik te ontmoeten of in contact te treden met de instelling, voorziening, organisatie of vereniging waarin het misbruik heeft plaatsgevonden, de slachtoffers informeren en ondersteunen als ze vragen om een bemiddeling met de vermeende (vermeende) pleger(s) van het misbruik of om hulpverlening, en hen informeren en ondersteunen als ze een beroep willen doen op justitie. Ten aanzien van deze opdrachten moet de commissie ook beleidsadviezen verstrekken aan de Vlaamse regering. ${ }^{12}$

8 Departement Welzijn, Volksgezondheid \& Gezin (2016). Erkennings- en Bemiddelingscommissie voor slachtoffers en na(ast)bestaanden van historisch misbruik. Definitief rapport.

9 Departement Welzijn, Volksgezondheid \& Gezin (2016), p. 18-19.

10 Resolutie betreffende voorstellen voor het versterken van de beleidsdomeinoverschrijdende aanpak tegen grensoverschrijdend gedrag: http://docs.vlaamsparlement.be/pfile?id=1414163 (stuk 1629 (2017-2018) - Nr. 4, ingediend op 4 juli 2018 en aangenomen door de plenaire vergadering).

11 Decreet 13 juli 2018 tot oprichting van de erkennings- en bemiddelingscommissie voor slachtoffers van historisch misbruik, BS 2 augustus 2018. 
De commissie bestaat uit ten minste zeven leden, die benoemd worden door de Vlaamse regering. ${ }^{13}$ Echter, het ontwerp van Besluit van de Vlaamse regering ter uitvoering van het Decreet - onder meer met betrekking tot de precieze afbakening van het toepassingsgebied - botste op een juridisch voorbehoud van de Raad van State. Momenteel (oktober 2020) wordt gewerkt aan nieuwe (decretale) regelgeving, waarbij het voorlopig onduidelijk is waar de commissie zal gehuisvest worden en hoe die zich zal verhouden tot de respectievelijke beleidsdomeinen (welzijn, sport, cultuur, ...) van de Vlaamse overheid.

In afwachting van het uitwerken van een definitief wettelijk kader voor de permanente commissie, werd de tijdelijke commissie gevraagd haar werkzaamheden verder te zetten via een projectsubsidie toegekend aan Moderator Forum voor Herstelrecht en Bemiddeling vzw, die de werking van de commissie ondersteunt. ${ }^{14}$

\section{Vergelijking van de twee responsmodellen}

In tal van landen werd de laatste twee decennia maatschappelijk initiatief genomen om enerzijds het fenomeen van historisch institutioneel misbruik te onderzoeken naar prevalentie, oorzaken en gevolgen en anderzijds specifieke responsmodellen uit te werken. Het onderzoek had vaak plaats in daartoe speciaal opgerichte onderzoekscommissies op initiatief van regeringen, parlementen of andere overheidsinstanties, op initiatief van de betrokken instituties zelf, zoals de kerk of een federatie/beroepsvereniging van betrokken organisaties, of op initiatief van nog andere actoren, zoals private instellingen, belangengroepen, universiteiten of andere onderzoeksinstellingen. In sommige landen behandelden de onderzoekscommissies ook de afhandeling of de respons in individuele dossiers, maar in vele landen werden daartoe afzonderlijke commissies of instanties opgericht. De twee hier bestudeerde Belgische initiatieven vallen onder deze laatste categorie, maar beide werden voorafgegaan door een bepaalde vorm van onderzoek, respectievelijk door een parlementaire onderzoekscommissie en een 'expertenpanel'. Informatie over de werkwijze en de resultaten van de redress schemes in de diverse landen kan teruggevonden worden op nationale websites en afzonderlijke rapporten en publicaties, maar vergelijkende studies zijn nauwelijks terug te vinden, enkele uitzonderingen niet te na gesproken (zoals Daly, 2014; Wright, 2017).

In dit onderdeel vergelijken we de twee Belgische responsmodellen op het vlak van politieke keuze, samenstelling, toepassingsgebied, werkwijze en (enkele) cijfergegevens.

13 Als benaming wordt thans gehanteerd: 'Commissie Erkenning \& Bemiddeling voor institutioneel misbruik en geweld uit het verleden', omdat slachtoffers aangaven dat de benaming 'historisch' misleidend is indien het gaat over feiten van 10 jaar geleden, die niet noodzakelijk verjaard zijn (www.comeb.be).

14 Commissie Erkenning \& Bemiddeling, Rapport van de periode 1 april tot 30 november 2019 (https://comeb.be/over-ons). 


\subsection{Politieke keuze}

Het uitgangspunt van de beleidsmatige keuzes voor beide modellen was de erkenning van het fenomeen als maatschappelijk probleem, dat dan ook een maatschappelijk antwoord behoefde. Het probleem werd met andere woorden niet herleid tot individueel slachtofferschap of een interne institutionele aangelegenheid, maar diende op breder maatschappelijk en politiek niveau onderzocht en geremedieerd te worden. Toch waren in beide gevallen in België - zoals in vele andere landen - extreme individuele getuigenissen of een schandaal nodig vooraleer het probleem erkend werd en een politieke actie tot stand kwam. Op dat ogenblik zijn er vele opties mogelijk: strafrechtelijke vervolging, burgerrechtelijke afhandeling (gericht op individuele of collectieve schadevergoeding), specifieke herstelprogramma's (redress schemes), herdenkingsinitiatieven, persoonlijke hulpverlening en therapie, bemiddeling of arbitrage, lotgenotenverenigingen, ... Voor historisch misbruik zijn de eerste twee mechanismen vaak onmogelijk wegens verjaring van de feiten. Men kan dan overgaan tot andere reacties, die kunnen variëren van louter symbolische gebaren of verklaringen tot financiële vergoeding. Maar ook de oprichting van een specifiek herstelrechtelijk mechanisme komt dan in het verschiet, al dan niet gecombineerd met andere van de hierboven vermelde opties.

Voor België werd door de politieke overheden telkens in de vorm van een parlementaire aanbeveling de optie genomen voor enerzijds een aangepaste arbitrageprocedure voor historisch misbruik in de kerk en anderzijds een onafhankelijke commissie voor erkenning en bemiddeling van historisch misbruik in jeugd-, onderwijs- en andere instellingen. De uitwerking van beide modellen lag in handen van respectievelijk een parlementaire opvolgingscommissie in nauwe samenwerking met vertegenwoordigers van de kerk en van de Vlaamse regering, waarbij tevens een beroep werd gedaan op organisaties voor hulpverlening en bemiddeling in Vlaanderen.

Belangrijk is dan nog het statuut te kennen van de respectievelijke herstelrechtelijke of herstelgerichte mechanismen, eens die opgericht waren. Beide zijn gekenmerkt door een zekere mate van onafhankelijkheid van de politieke instanties die hen hebben opgericht: het Centrum voor Arbitrage (en de daarbij aansluitende scheidsrechtelijke voorziening) kreeg zelf geen rechtspersoonlijkheid, maar werd opgericht en functioneerde op basis van een hiertoe in onderling overleg opgesteld 'Arbitragereglement', waarbij de personeelsomkadering, werking en huisvesting werden mogelijk gemaakt door een financiering van de minister van Justitie enerzijds en de Koning Boudewijnstichting in Brussel anderzijds, en waarbij ook de kerk een deel van de financiering voor haar rekening nam. ${ }^{15}$ De Vlaamse Commissie voor Erkenning en Bemiddeling heeft evenmin rechtspersoonlijkheid, functioneert onafhankelijk op basis van het nog uit te voeren decreet en een intern reglement en wordt administratief en financieel ondersteund door de Vlaamse regering, sedert 2019 via Moderator Forum voor herstelrecht en bemiddeling vzw. Hoewel beide modellen op administratief en financieel vlak een gedeeltelijke afhankelijkheid kenden/kennen van de overheid, functioneerden/ 
functioneren zij in hun inhoudelijke werking op volstrekt onafhankelijke basis ten opzichte van mogelijke politieke of andere inmenging.

\subsection{Samenstelling}

Het federale arbitragemodel voor misbruik in de kerk bestond uit een Wetenschappelijk Comité, een Permanente Arbitragekamer, een lijst van arbiters en een juridisch secretariaat. Het Wetenschappelijk Comité had als taak de bepalingen van het Arbitragereglement te interpreteren en, zo nodig, aan te vullen door niet geregelde vragen te beslechten. Daarnaast stond het Comité in voor de tussentijdse en eindrapportage aan de parlementaire opvolgingscommissie, hiertoe ondersteund door het juridisch secretariaat (één persoon). Naast het regelmatig verzamelen van cijfergegevens werd niet aan wetenschappelijk onderzoek gedaan. Dit Comité werd evenwichtig samengesteld op basis van taalrol, maar ook ideologische strekking (twee leden waren aangesteld door het parlement en twee leden door de kerkelijke instanties). Dit laatste gold in zekere zin ook voor de Permanente Arbitragekamer, die bestond uit zeven personen en multidisciplinair was samengesteld (juristen, medisch-psychiatrische sector, welzijnssector en criminologie). Deze werden aangesteld door het Wetenschappelijk Comité. ${ }^{16}$

De taken van de Permanente Arbitragekamer betroffen de controle van de ontvankelijkheid van een aanvraag, de poging tot verzoening van de partijen, in voorkomend geval het doorsturen naar arbitrage of bemiddeling, en controle van de arbitrageprocedure. Het scheidsgerecht of arbitraal college bestond voor elk dossier uit drie arbiters, onder wie een voorzitter, waarbij aanvrager (slachtoffer) en verweerder (de kerk, bij monde van het orgaan 'Dignity') elk vrij een arbiter kozen uit een van de drie door het Wetenschappelijk Comité opgestelde lijsten, met personen uit respectievelijk de zorgsector (artsen, psychologen, psychiaters en psychotherapeuten), de welzijnssector (met ervaring op het gebied van criminologie, victimologie, herstelrecht of sociale bijstand) en een lijst van juristen, waaruit door beide partijen de voorzitter gekozen werd.

De structuur van de Vlaamse Commissie voor Erkenning en Bemiddeling is veel eenvoudiger. Ze bestond aanvankelijk uit negen commissieleden, waarvan er momenteel nog steeds zeven in functie zijn. De commissieleden zijn geselecteerd op basis van hun expertise op het vlak van slachtofferbejegening, bemiddeling en/ of ervaring met situaties van grensoverschrijdend gedrag en werden op voordracht van de administratie door de minister verantwoordelijk voor het Departement Welzijn, Volksgezondheid en Gezin benoemd. ${ }^{17}$ De commissie is divers samengesteld wat gender- en leeftijdsverdeling, professionele achtergrond en sectoren betreft. ${ }^{18}$ De commissie werd in een eerste periode aangestuurd door een medewerker van het Departement Welzijn, Volksgezondheid en Gezin (Deblauwe, 2019). Bij de omvorming van de commissie naar een permanente instantie door het parlementaire Decreet (2018) werd voorzien dat er minstens zeven

18 Departement Welzijn, Volksgezondheid \& Gezin (2016), p. 5. 
commissieleden moeten zijn met relevante expertise op het vlak van misbruik. De commissie wordt sinds april 2019 aangestuurd door een coördinator, die door Moderator vzw aangeworven is met de toegekende subsidie van de Vlaamse overheid.

De samenstelling van beide voorzieningen is verschillend, maar in beide gevallen valt de multidisciplinariteit op.

\subsection{Toepassingsgebied}

Het Centrum voor Arbitrage was bevoegd voor strafrechtelijk verjaarde feiten van seksueel misbruik, waarbij het slachtoffer geen partij mocht zijn in een andere hangende procedure voor dezelfde feiten. ${ }^{19}$ De feiten dienden gepleegd te zijn toen het slachteroffer minderjarig was (op het ogenblik van de feiten). De pleger diende een priester van een Belgisch bisdom te zijn of een (mannelijk of vrouwelijk) lid van een religieuze congregatie of orde die in België is gevestigd (dus eventueel ook voor feiten die door één van hen in het buitenland gepleegd werden). In geval van zelfdoding door het slachtoffer - met een duidelijk oorzakelijk verband met het misbruik - konden bepaalde verwanten eveneens een aanvraag indienen. Aanvragen konden ingediend worden tot 31 oktober 2012. De toepassing van de hierboven vermelde criteria (en dus de ontvankelijkheid van de aanvragen) werd telkens nagegaan door de Permanente Arbitragekamer.

De Vlaamse Commissie voor Erkenning en Bemiddeling heeft een veel ruimer toepassingsgebied. ${ }^{20}$ Vooreerst hebben hoedanigheid of leeftijd van slachtoffer of (vermeende) pleger geen enkel belang: het slachtoffer kon dus minderjarig of meerderjarig zijn op het ogenblik van de feiten. Maar ook de (vermeende) pleger kon minderjarig zijn. Denk bijvoorbeeld aan een jeugdinstelling waar een jongere feiten pleegt op andere kinderen. De (vermeende) pleger hoeft uiteraard geen religieuze hoedanigheid te hebben en kan eender welke persoon zijn die op één of andere wijze aan een instelling, voorziening, organisatie of vereniging verbonden is. Op het ogenblik van het schrijven van dit artikel is zelfs niet duidelijk of de feiten noodzakelijkerwijze in institutioneel verband moeten gepleegd worden,

19 Afhankelijk van het tijdstip van de feiten en de toen geldende wetgeving, betrof deze verjaringstermijn voor de meeste dossiers tien jaar, te tellen vanaf de datum van het bereiken van de meerderjarigheid voor het slachtoffer (naargelang de feiten dateerden van voor of na 1 mei 1990 ging de meerderjarigheid wettelijk in op 21 dan wel 18 jaar). Op aanbeveling van de parlementaire Bijzondere Commissie werd de verjaringstermijn voor seksuele misdrijven gepleegd ten aanzien van minderjarige slachtoffers in 2011 wettelijk uitgebreid naar 15 jaar vanaf het bereiken van de leeftijd van 18 jaar. Wie geïnteresseerd is in de juridisch complexe materie van de verjaring, de wijze waarop deze door het Centrum voor Arbitrage onderzocht werd en de implicaties van de verjaringsconditie voor onder meer de vertrouwelijkheid van de procedure, leze het Eindverslag van het Wetenschappelijk Comité, p. 11-16 en elders (zie voetnoot 1 hierboven). Nadien vonden nog twee wetswijzigingen plaats, namelijk één bij wet van 31 mei 2016 (waarbij in geval van eenheid van opzet de verjaringstermijn slechts begint te lopen wanneer het jongste slachtoffer 18 jaar wordt) en één bij wet 14 november 2019, gewijzigd bij wet van 5 december 2019 (waarbij ernstige feiten van seksueel misbruik van minderjarigen onverjaarbaar werden). Deze respectievelijke wijzigingen werken evenwel niet retroactief en maken de analyse van het al dan niet verjaard zijn van de feiten bijzonder complex. De eenzijdige focus op seksueel geweld, ten nadele van fysiek of psychisch geweld roept eveneens vragen op. 
dan wel of de commissie tevens dossiers van intrafamiliaal geweld kan opnemen, gezien deze niet door het decreet worden uitgesloten. De commissie heeft haar mandaat evenwel steeds in die zin geïnterpreteerd en meldingen inzake intrafamiliaal geweld onontvankelijk verklaard (ongeveer één op vier meldingen). Niettemin heeft ze de hoge nood van slachtoffers van intrafamiliaal geweld om erkenning te krijgen vastgesteld en daarom in 2020 in enkele dossiers (v)erkenningsgesprekken aangevat.

Wat de feiten betreft, kan het niet enkel om seksueel geweld gaan, maar kan het ook fysiek of psychisch geweld of verwaarlozing betreffen. Verder dient het om feiten te gaan die op het ogenblik van de aanmelding bij de commissie minstens tien jaar geleden plaatsvonden. Alhoewel de leden van het Vlaamse parlement wellicht de verjaringstermijn inzake misdaden in het achterhoofd hadden, kan het dus in principe ook om niet-verjaarde feiten gaan. ${ }^{21} \mathrm{~A}$ priori zou het om feiten moeten gaan die in Vlaanderen werden gepleegd, maar ook dit is niet duidelijk afgebakend in het decreet. Waar de tijdelijke commissie aanvragen onontvankelijk verklaarde indien de aanmelder ook een dossier bij de PAK had ingediend, is dit criterium door het opheffen van de PAK komen te vervallen. ${ }^{22}$

\subsection{Werkwijze}

\section{- Het Centrum voor Arbitrage}

De werkwijze van het Centrum voor Arbitrage betrof een 'gemengde' procedure waarbij - in tegenstelling tot wat zijn naam doet vermoeden - verschillende conflictoplossingsmethoden konden toegepast worden: arbitrage, bemiddeling en verzoening. Deze werkvormen werden in de Inleiding van het Arbitragereglement als volgt omschreven, conform de gangbare definities in de literatuur:

- 'Arbitrage' is een procedure om een geschil te laten beslechten, buiten de gewone hoven en rechtbanken om, door een beroep te doen op onafhankelijke arbiters die aangeduid worden omwille van hun expertise in de materie. Hun beslissing (of arbitrale uitspraak) is bindend voor de partijen.

- 'Bemiddeling' is een procedure waarin een derde, onafhankelijke en onpartijdige persoon (de bemiddelaar) van de partijen de opdracht krijgt om hen te helpen om tot een minnelijke regeling te komen. De bemiddelaar heeft niet de bevoegdheid om aan de partijen een bepaalde oplossing van het geschil op te leggen.

- De 'verzoening' is een stap binnen de arbitrageprocedure waarbij de personen die werden aangewezen om een uitspraak te doen, op tegensprekelijke wijze pogen de partijen ertoe te brengen hun geschil via dialoog te beslechten, zodat het tot een regeling kan komen die de beide partijen tevreden stemt. In

21 Zie voetnoot 19 hierboven inzake de verjaring van bepaalde seksuele misdrijven. Ook feiten van fysiek of psychisch geweld of van verwaarlozing zijn evenwel niet noodzakelijk verjaard omwille van schorsing of stuiting of door eenheid van opzet met andere niet-verjaarde feiten.

22 Departement Welzijn, Volksgezondheid \& Gezin (2016), p. 8; Commissie Erkenning \& Bemiddeling, Rapport van de periode 1 april tot 30 november 2019, www.comeb.be/over-ons, p. 11. 
het raam van hun taak hebben de verzoeners een actieve rol in de dialoog tussen de partijen en kunnen zij een voorstel tot regeling formuleren.

Anders dan initieel verwacht (men vermoedde dat de meeste dossiers zouden behandeld worden via 'arbitrage'), werd de overgrote meerderheid van de dossiers afgehandeld via 'verzoening' (voor 504 van de 628 dossiers werd een verzoening bereikt). In geen enkel dossier werd vanuit de procedure een beroep gedaan op een externe bemiddelaar of bemiddelingsdienst (hoewel hiertoe afspraken werden gemaakt met een organisatie als Suggnomè/Moderator vzw). ${ }^{23}$ Van de formele 'arbitrage' (scheidsgerecht) werd, zoals reeds vermeld, slechts gebruikgemaakt in drie dossiers (aangezien een overeenkomst kon bereikt worden in de verzoeningsfase). ${ }^{24}$ Zoals hiervoor vermeld konden slachtoffers tot op een bepaalde datum hun schriftelijke aanvraagdossier indienen bij het secretariaat van het Centrum voor Arbitrage, gehuisvest bij de (neutrale, onafhankelijke en gerespecteerde) Koning Boudewijnstichting in Brussel. Dit diende te gebeuren door middel van een formulier 'Aanvraag voor billijke herstelmaatregelen', waar betrokkenen gegevens dienden in te vullen over hun identiteit, de beschrijving van de feiten (met inbegrip van indicaties rond de vermoedelijke pleger en zijn/ haar werkplek), eventueel lopende procedures, het voorwerp van de aanvraag ${ }^{25}$ en bijkomende inlichtingen. Daarnaast konden onbeperkt bijlagen toegevoegd worden (getuigenissen, brieven, foto's, krantenartikelen, medische of psychiatrische verslagen, bewijsstukken van gemaakte medische en andere kosten, ...). $\mathrm{Na}$ een eerste juridisch onderzoek van de ontvankelijkheid van de aanvraag werd een kopie van het dossier overgemaakt aan de Stichting Dignity, als vertegenwoordiger van de Kerk in de opeenvolgende stappen van de procedure, en aan de leden van de Permanente Arbitragekamer. Op basis van dit dossier kon enerzijds Dignity een onderzoek doorvoeren naar de (herkenbaarheid van de) feiten en eventueel bijkomende gegevens verzamelen, en konden anderzijds de leden van de PAK het gesprek met het slachtoffer voorbereiden. Dit gesprek had dus plaats in het Centrum voor Arbitrage in aanwezigheid van twee of drie leden van de PAK (steeds bestaande uit twee verschillende disciplines: juridische en hulpverleningsdiscipline), het slachtoffer, eventueel bijgestaan door een familielid, advocaat,

23 Het achterwege blijven van bemiddeling kan verklaard worden door verschillende factoren: het niet meer beschikbaar zijn van een persoonlijke dader (de geestelijke: overleden, ziek, behoeftig ...), de afwezigheid van een behoefte om een gesprek te hebben met het instituut (de school, de parochie, ...) omdat het institutionele niveau van de kerk al aanwezig was op de zittingen in de figuur van Dignity die vaak voorafgaand een onderzoek had uitgevoerd in de betreffende instelling, een weerstand of gebrek aan bekendheid met bemiddelingsprocedures langs de kant van de Dignity-vertegenwoordigers, een onvoldoende proactieve houding van de leden van de PAK en de vrees voor overbelasting van het slachtoffer, ...

24 De overige van de 628 ingediende dossiers werden om uiteenlopende redenen beëindigd (bijv. wegens onontvankelijkheid of afstand).

25 'Leg bondig uit wat $\mathrm{u}$ wil bekomen door de arbitrageprocedure. U kan preciseren dat $\mathrm{u}$ een bijzondere vorm van erkenning van het leed ten gevolge van het misbruik wenst (bijv. een erkenning van de feiten, een gesprek, een brief met spijtbetuiging of met excuses ...). Preciseer ook of $u$ een financiële compensatie verwacht, en of uw voorkeur uitgaat naar een minnelijke regeling.' 
hulpverlener of ander vertrouwenspersoon, en twee leden van Dignity ${ }^{26}$ (desgevallend ook bijgestaan door een advocaat).

Deze gesprekken met de PAK - meestal uitmondend in een verzoening - zijn dus de kern gaan vormen van de afhandeling. Gaandeweg is er zich een bepaalde 'methodiek' gaan ontwikkelen om deze gesprekken en de positieve uitkomst mogelijk te maken: onthaal van het slachtoffer, toelichting van de procedure, het (vaak zeer emotionele en uitgebreide) verhaal van het slachtoffer, ${ }^{27}$ de reactie van de vertegenwoordigers van Dignity en eventueel hun bijkomende gegevens over de feiten, verdere vragen en wensen van het slachtoffer en antwoorden van Dignity. Een belangrijk bestanddeel bestond in het creëren van een veilig, respectvol en begripvol klimaat, waardoor een persoonlijke en diepgaande vorm van spreken en luisteren mogelijk werd. In vrijwel alle gevallen werd het slachtoffer door Dignity geloofd op zijn/haar woord (en op basis van het ingediende dossier en eventueel verder intern onderzoek), hoewel juridisch meestal geen bewijs kon geleverd worden. In de gesprekken werd deze aanname van de feiten door Dignity ook expliciet bevestigd, gevolgd door een nadrukkelijke afkeuring van de feiten en de erkenning van de diverse gevolgen voor het slachtoffer. Doorgaans werden vervolgens excuses aangeboden uit naam van de kerk. Na deze fase werd op initiatief van de leden van de PAK overgegaan tot het gesprek over een mogelijke financiële tegemoetkoming. Hierbij werd doorgaans door de leden van de PAK een voorstel geformuleerd, op basis van de categorieën van feiten naar ernstgraad en daarbij horende bedragen zoals bepaald in het Arbitragereglement. ${ }^{28}$ Vrij gemakkelijk werd, in de meeste gevallen (bijna 80\%), door de partijen (slachtoffer en Dignity) een vergelijk bereikt rond dit bedrag. Hierop volgend werd de bekomen overeenkomst (rond financiële en andere aspecten) neergeschreven in een 'proces-verbaal van minnelijke regeling' en dit volgens een standaardmodel, te

26 Het betrof doorgaans vaste vertegenwoordigers van Dignity, met name een hiërarchisch hoger geplaatste geestelijke (een kanunnik) en een ervaren stafmedewerker. Met één uitzondering was de pleger nooit aanwezig en dit wegens (meestal) overlijden of ongeschiktheid van de persoon in kwestie.

27 Slachtoffers werden aangemoedigd, maar niet verplicht, hun verhaal te brengen over de feiten en over de eventuele gevolgen op diverse levensdomeinen (eigen gezin, school en leerprestaties, sociale omgeving en omgang met leeftijdsgenoten, het latere relationele, familiale en professionele leven, ....).

28 Het Arbitragereglement bepaalde de volgende categorieën en maximumbedragen:

Categorie 1: maximaal $€ 2.500$

- $\quad$ aanranding van de eerbaarheid zonder geweld of bedreiging

Categorie 2: maximaal $€ 5.000$

- $\quad$ aanranding van de eerbaarheid met geweld of bedreiging, of

- $\quad$ aanranding van de eerbaarheid zonder geweld of bedreiging op een minderjarige onder 16 jaar of op een minderjarige met bijzondere kwetsbaarheid

Categorie 3: maximaal $€ 10.000$

- verkrachting van een minderjarige

Categorie 4: maximaal $€ 25.000$

- $\quad$ aanranding of verkrachting, die, gezien de ernst, de langdurigheid of de bijzondere omstandigheden van het seksueel misbruik, als uitzonderlijk dient te worden beschouwd en die heeft geleid tot een aantoonbare buitengewone schade waarvan het causaal verband met het seksueel misbruik is bewezen. 
ondertekenen door alle betrokken partijen (slachtoffer, Dignity en leden van de PAK). De afronding van het gesprek voorzag ook - althans aan Vlaamse kant en waar dit volgens de leden van de PAK aangewezen was - in een aanbod van doorverwijzing van het slachtoffer naar één van de Centra voor Geestelijke Gezondheidszorg in Vlaanderen of Brussel waarmee afspraken dienaangaande gemaakt waren.

Enkele weken na het ondertekenen van de overeenkomst werd het compensatiebedrag door Dignity via bankoverschrijving betaald aan het slachtoffer. Voor deze regeling werd door de bisdommen en congregaties/ordes een intern 'fonds' gecreëerd, waaruit de bedragen rechtstreeks aan het slachtoffer konden overgemaakt worden. Daaropvolgend werden - waar mogelijk - de uitbetaalde bedragen intern verrekend en/of verhaald op de pleger of zijn instelling.

\section{- De Commissie Erkenning \& Bemiddeling}

Om de toegang van slachtoffers zo ruim mogelijk te maken bouwt de commissie bij het beoordelen van de ontvankelijkheid van aanmeldingen geen beperkingen in qua tijd, noch op basis van eerder ondernomen stappen, noch op basis van mogelijke motieven van de slachtoffers. De ontvankelijkheid wordt enkel bepaald door het mandaat van de commissie. Ondanks het eerdere bestaan van de PAK, melden zich nog slachtoffers van misbruik door religieuzen en priesters. Sommigen waren destijds niet klaar om zich te melden of waren slachtoffer van nietseksueel misbruik. Anderen willen zich niet tot de interne meldpunten in de kerk wenden, omdat ze de kerk als betrokken partij zien. Nog anderen vinden de weg naar de commissie langs andere kanalen. Ook slachtoffers die destijds door het Centrum voor Arbitrage gehoord zijn, kunnen zich nog tot de commissie wenden, indien zij een bijkomende behoefte tot erkenning hebben. Van de vijftien in 2019 door de Commissie behandelde dossiers was de (vermeende) pleger in dertien gevallen een geestelijke, doorgaans een leerkracht, opvoeder of parochiepriester. In geval van een onontvankelijke aanmelding (inzake intrafamiliaal geweld), vinden meestal meerdere contacten met de aanmelder en externe instanties plaats om de aanmelder zo gepast mogelijk door te verwijzen en deze doorverwijzing verder op te volgen.

$\mathrm{Na}$ een eerste contact, doorgaans per telefoon of e-mail met de coördinator, en indien de aanmelding prima facie ontvankelijk lijkt te zijn, wordt gevraagd om een aanmeldingsformulier in te dienen. Hierin wordt beknopt gevraagd naar de aard van de feiten, leeftijd van aanmelder, tijdstip van de feiten, aard van de instelling, hoedanigheid van de (vermeende) pleger, enzovoort. Ook wordt gepolst wat de verwachtingen van de aanmelder zijn (zoals erkenning, bemiddeling, doorverwijzing). $\mathrm{Na}$ ontvangst wordt spoedig een eerste gesprek met de commissie vastgelegd.

Anders dan bij de PAK wordt bij de Commissie Erkenning \& Bemiddeling doorgaans een traject opgestart, dat soms tot een jaar of langer kan duren en doorgaans meerdere gesprekken omvat. Elk dossier wordt door telkens dezelfde twee commissieleden gevolgd, waarvan altijd één bemiddelaar en meestal met één man en één vrouw. Het merendeel van de gesprekken wordt bijgewoond door de coördinator, die instaat voor de tussentijdse opvolging. Tijdens de gesprekken kan een 
vertrouwenspersoon van het slachtoffer aanwezig zijn. De gesprekken vinden plaats in de lokalen van de commissie in Leuven, of op een andere locatie indien de betrokken partij(en) dat wensen.

Alle trajecten bij de commissie verlopen op basis van vrijwilligheid en op basis van de wensen en behoeften van de betrokkenen. De commissie is voorstander van een aanpak op maat. In dezen lijkt het belangrijk dat slachtoffers - die als kind van elk keuzerecht zijn beroofd - de keuze hebben om één of meer wegen te kiezen, op basis van correcte informatie. Vaak wil een slachtoffer in eerste instantie alleen maar gehoord worden. Daarbij bepaalt het slachtoffer zelf wat hij of zij wil vertellen. Vaak worden dan nog geen details over de feiten vermeld. Soms komt dit pas later aan bod of wil het slachtoffer er alleen schriftelijk iets over kwijt. In de loop van de gesprekken komen vaak bijkomende noden en vragen aan het licht.

Het niet geloofd of gehoord zijn geweest heeft voor veel slachtoffers tot op vandaag ingrijpende gevolgen. Ze zijn dan ook in eerste instantie op zoek naar erkenning door de samenleving van de feiten en het leed dat hun is aangedaan. Tijdens een erkenningsgesprek wordt een luisterend oor geboden aan de aanmelder en wordt namens de samenleving erkenning geboden voor het misbruik, geweld en/ of verwaarlozing en voor het leed dat aan het slachtoffer werd aangedaan, zonder hun relaas in vraag te stellen. Doorheen deze gesprekken met slachtoffers kan worden vastgesteld hoeveel voldoening ze halen uit het gehoord en geloofd worden. Dit op zich is reeds een vorm van herstel of genoegdoening. Sommige aanmelders wensen alleen deze erkenning en eventueel doorverwijzing naar gepaste hulpverlening of juridisch advies. Niet elke aanmelder heeft dus (in eerste instantie) een vraag naar bemiddeling met de (vermeende) pleger en/of met de betrokken instanties, maar in dertien van de vijftien in 2019 behandelde dossiers was dit wel het geval.

Voor anderen is een oprechte erkenning door de (vermeende) pleger en/of instelling, gevolgd door gemeende excuses door de (vermeende) pleger zelf en eventueel de verantwoordelijke instelling, echter van groot belang. Deze vraag leidt tot het opstarten van een bemiddelingstraject, met als eerste doelstelling het bekomen van een specifieke vorm van erkenning. A priori neemt de commissie deze bemiddelingen zelf op. Enerzijds besteedt de commissie veel aandacht aan het opbouwen van een vertrouwensrelatie met alle betrokken partijen - maar vooral met slachtoffers die door hun negatieve ervaring vaak wantrouwig zijn - en zou het contraproductief zijn het slachtoffer dan opnieuw door te verwijzen. Anderzijds toont de praktijk ook aan dat de verhouding van het slachtoffer tot de instelling en die tot de (vermeende) pleger vaak nauw verweven zijn en dat het tegennatuurlijk zou zijn deze complexe problematiek uit te splitsen in twee afzonderlijke trajecten voor bemiddeling.

Ook de bemiddeling verloopt in verschillende stappen: gesprekken met de aanmelder (doorgaans het slachtoffer) worden gevolgd door contactname met de instelling en/of de (vermeende) pleger. Indien de (vermeende) pleger nog in leven is en bereid is om mee te werken, wordt eerst een gesprek met deze persoon gevoerd. Indien de verantwoordelijke van de betrokken instelling wil meewerken, wordt een eerste gesprek met het slachtoffer doorgaans telefonisch voorbereid. 
De commissieleden hanteren tijdens de gesprekken het principe van de meerzijdige partijdigheid, waarbij ze geen partij kiezen voor of tegen de ene of andere betrokkene. Dit is ook zo wat de (vermeende) plegers en verantwoordelijken van instellingen betreft, die met hetzelfde respect behandeld worden als de andere betrokkenen. De commissie stelt vast dat deze aanpak kan beantwoorden aan een behoefte van de (vermeende) pleger die zelf ook met zijn verleden in het reine wil komen en erkenning wil bieden via een bemiddelingstraject, nood kan hebben aan hulpverlening of aan begeleide begrenzing.

De wonden die door het misbruik of geweld geslagen zijn, kunnen niet meer ongedaan gemaakt worden. Niettemin kunnen kleine beetjes helpen. Herstel neemt tot op heden in de behandelde dossiers allerlei vormen aan: een brief aan de (vermeende) pleger over de feiten en de gevolgen ervan, een brief met erkenning en excuses, het aanpassen van een overlijdensbericht op een website, een gesprek over het huidige preventiebeleid in de instelling, enzovoort.

Een vraag naar bemiddeling met de betrokken instantie is dus niet noodzakelijk een vraag naar financiële tegemoetkoming, waarvoor er meestal omwille van verjaring toch geen rechtsgrond bestaat. Indien er een vraag of aanbod is voor een financiële tegemoetkoming (die soms nog door de meldpunten van de kerk wordt toegekend, ook na de opheffing van het Centrum voor Arbitrage), is dat vaak slechts bijkomstig, en altijd ondergeschikt aan het belang van erkenning. De commissie begeleidt desgewenst de slachtoffers in dit proces.

De commissie vindt het zeer belangrijk dat slachtoffers en (vermeende) plegers ook buiten de gesprekken met de commissie goed omkaderd zijn en zal hen desgevallend naar hulpverlening of lotgenotengroepen doorverwijzen. Dit geldt ook voor de vertrouwenspersonen of tussenpersonen van de instellingen.

Aan het einde van het traject vindt een afsluitend gesprek met de aanmelder plaats, waarin ook wordt gepolst welke impact het traject heeft gehad en wordt gevraagd aanbevelingen te maken voor de verdere werking en verbetering van de werking van de commissie. Afsluitend wordt nog een schriftelijk evaluatieformulier toegestuurd.

\subsection{Enkele cijfers en gegevens}

\section{- Het Centrum voor Arbitrage}

Het Eindverslag van het Wetenschappelijk Comité (zie hoger) bevat een aantal cijfergegevens die gedurende de vier jaar durende werking van het Centrum voor Arbitrage verzameld werden. De belangrijkste hiervan zijn de volgende. Van de in totaal 628 aanvragen werd 71\% ingediend door Nederlandstaligen en bijna 80\% van de aanvragers waren mannen. ${ }^{29} 38$ aanvragen werden gedaan vanuit het buitenland (Europa of daarbuiten). De grootste leeftijdsgroep (op het ogenblik van de aanvraag) is tussen de 50 en 69 jaar (64\% van alle aanvragen). De leeftijd van

29 Een gelijkaardige verdeling op het vlak van geografische spreiding en geslacht (met een groot overwicht van dossiers vanuit Vlaanderen en mannelijke aanvragers) werd ook vastgesteld voor de 424 aanvragen die ingediend werden bij de commissie-Adriaenssens in de periode april-juni 2010 (Adriaenssens, 2010; Aertsen \& De Ranter, 2012). 
de slachtoffers op het moment van de eerste feiten betrof in 35\% van de dossiers 8 tot 11 jaar, in $42 \%$ was dit 12 tot 15 jaar. Dader en slachtoffer zijn voor het eerst in contact met elkaar gekomen in een school (ongeveer $50 \%$ van alle dossiers) of een kerk (ongeveer 25\%). De meeste aanvragen behoorden tot categorie 2 (afgerond 54\%), gevolgd door categorie 3 (36\%), categorie 1 (5\%) en categorie 4 (4\%). ${ }^{30}$ Vier dossiers betroffen zelfdoding. In totaal werd in 507 (ongeveer $80 \%)$ van de aanvragen een financiële vergoeding toegekend, goed voor bijna $€ 3$ miljoen, met een gemiddelde van $€ 5.916$ per dossier.

Ongeveer $20 \%$ van de slachtoffers ging niet in op de uitnodiging tot een ontmoeting met de PAK. In $47 \%$ van de ontmoetingen met de PAK trad het slachtoffer alleen op, in ongeveer $6 \%$ werd het vertegenwoordigd door een advocaat, in ongeveer $15 \%$ was het slachtoffer aanwezig mét een advocaat, in ongeveer $15 \%$ vergezeld van een familielid en in ongeveer $4 \%$ bijgestaan door een professionele hulpverlener. In totaal werden door de PAK gedurende de vier jaren durende werking 173 ontmoetingsmomenten met slachtoffers en Dignity georganiseerd. ${ }^{31}$

\section{- De Commissie Erkenning \& Bemiddeling}

De cijfers voor de Commissie Erkenning \& Bemiddeling liggen beduidend lager. Nochtans blijkt uit de actualiteit dat de noden groot zijn. Geregeld duiken nieuwe feiten en schandalen op in de cultuursector, sportwereld, de media, enzovoort. Ook wat intrafamiliaal geweld uit het verleden betreft, zijn de noden zeer hoog.

Het uitblijven van het definitieve wettelijke kader van de permanente commissie heeft haar evenwel belet om aan ruime bekendmaking te doen, waardoor haar bestaan en werking nog relatief onbekend zijn. Wel werden contacten gelegd met lotgenoten- of belangengroepen en andere mogelijke doorverwijzende instanties. Nieuwe aanmeldingen komen doorgaans via lotgenoten binnen, via Moderator vzw, via het nummer 1712 of via de webpagina. ${ }^{32}$ Vele aanmelders zeggen eerder toevallig bij de commissie terecht te zijn gekomen.

In de periode 2014-2015 ontving de commissie negentien aanmeldingen, waarvan er veertien werden opgenomen. Het ging om vijf mannelijke en veertine vrouwelijke slachtoffers, die op het ogenblik van de aanmelding voor het merendeel tussen de 50 en 70 jaar oud waren. De feiten vonden meestal plaats in de periode 1940-1970, toen de slachtoffers tussen de 3 en de 12 jaar oud waren. Het betrof vaak een combinatie van aanhoudend fysiek en psychisch geweld en verwaarlozing. Negen slachtoffers ontmoetten de huidige leidinggevende van de voorziening waar het misbruik had plaatsgevonden. De commissie ontmoette in één dossier een genoemde dader. Negen slachtoffers hadden behoefte aan een ontmoeting of contact met lotgenoten en andere slachtoffers. Enkele aanmelders werden doorverwezen voor therapeutische begeleiding. ${ }^{33}$

30 Zie noot 28 voor de beschrijving van de categorieën.

31 De ontmoetingsmomenten bedroegen een hele of een halve dag. Per dagdeel werd een tweetal slachtoffers gezien.

32 De webpagina op de site van Moderator vzw werd inmiddels omgevormd tot een eigen website: www.comeb.be.

33 Departement Welzijn, Volksgezondheid \& Gezin (2016), p. 10. 
In de periode van 1 april tot 30 november $2019^{34}$ behandelde de commissie 23 aanmeldingen, waarvan zeventien ontvankelijk waren (zes betroffen intrafamiliaal geweld) en vijftien uiteindelijk behandeld werden. De onderstaande gegevens hebben betrekking op deze vijftien dossiers. In elk dossier op twee na vond minstens één erkenningsgesprek plaats. In veertien dossiers was er een vraag tot bemiddeling met de (vermeende) pleger en/of instelling. In zes dossiers werden effectief bemiddelingstrajecten opgestart. In andere dossiers werden voorbereidende stappen gezet om dit te doen.

Het misbruik situeerde zich in hoofdzaak op school, voor het merendeel in internaten (negen van vijftien aanmeldingen) of in plaatselijke afdelingen van kerken (katholieke parochies of protestantse kerken: drie feiten), in een jeugdinstelling (twee) en één in het kader van tewerkstelling in een organisatie.

In elf van de vijftien dossiers was er minstens sprake van seksueel misbruik. In de andere dossiers ging het om fysiek en/of psychisch geweld. In de meerderheid van de dossiers was sprake van herhaald of aanhoudend (i.e. meerdere jaren) geweld. In slechts vier op de vijftien dossiers was er sprake van eenmalig geweld of misbruik. De feiten in vijf van de vijftien dossiers deden zich voor in de jaren zeventig, vier in de jaren tachtig, drie in de jaren zestig, twee in de jaren vijftig en één in de jaren negentig.

Alle slachtoffers in deze dossiers waren mannen. De slachtoffers in de zes aanmeldingen van intrafamiliaal geweld (die onontvankelijk werden verklaard) waren vijf vrouwen en één man. De meesten zijn op het ogenblik van de aanmelding tussen 50 en 76 jaar oud. De leeftijd van het eerste misbruik situeerde zich doorgaans rond de (pre)puberteit: tussen 8 en 14 jaar. Dit is het geval in elf van de vijftien dossiers. Twee slachtoffers waren al volwassen op het ogenblik van de feiten. Eén slachtoffer was een kind van 3 jaar op het ogenblik van de feiten, een ander was 4 jaar bij aanvang van de feiten.

De (vermeende) pleger was doorgaans een leerkracht of opvoeder met de hoedanigheid van religieus, of een parochiepriester die in een gezagsrelatie stond ten opzichte van het slachtoffer. Slechts in twee dossiers waren de (vermeende) daders leken. Op twee na waren alle (vermeende) daders mannen. De vrouwelijke (vermeende) daders waren allebei leerkracht, waarvan één religieuze. Alle vermeende daders waren volwassenen. In zeven dossiers bleek er nog een (vermeende) pleger in leven te zijn. Met enkele daarvan kon in 2019 al een bemiddelingstraject worden aangevat, terwijl andere in 2020 werden opgestart.

\section{Analyse}

\subsection{Herstelrechtelijke aanknopingspunten}

In welke mate kunnen beide Belgische responsmodellen ten aanzien van institutioneel misbruik en geweld uit het verleden 'herstelrechtelijk' genoemd worden? Om deze vraag te beantwoorden gaan we uit van een vrij algemeen aanvaarde 
omschrijving van 'herstelrecht', zoals die terug te vinden is in de twee volgende definities:

"'Restorative justice" refers to any process which enables those harmed by crime, and those responsible for that harm, if they freely consent, to participate actively in the resolution of matters arising from the offence, through the help of a trained and impartial third party (hereinafter the "facilitator"). 35

'Restorative justice is an approach of addressing harm or the risk of harm through engaging all those affected in coming to a common understanding and agreement on how the harm or wrongdoing can be repaired and justice achieved. $^{36}$

In beide definities zijn zowel het participatieve element ('alle betrokkenen') als de herstelgerichte oriëntatie (gericht op oplossing, gemeenschappelijk begrip, overeenkomst rond herstel van schade of onrecht en bekomen van gerechtigheid) duidelijk aanwezig als noodzakelijke bestanddelen. De hierboven geschetste responsmodellen voor historisch misbruik en geweld bevatten op het eerste zicht een aantal van deze elementen, maar behoeven toch enkele verduidelijkingen, nuanceringen en reflecties.

Het Centrum voor Arbritage voor seksueel misbruik in de kerk, zoals voorgesteld door de parlementaire Bijzondere Commissie en later door vertegenwoordigers van parlement en kerk uitgewerkt in een arbitragereglement, kende van meet af aan een zekere herstelrechtelijke insteek, zij het deels uit noodzaak: strafrechtelijke vervolging was niet meer mogelijk. Toch heeft men een eigen, origineel mechanisme van herstel op de been willen brengen, geïnspireerd door (de wettelijke voorziene mogelijkheid van) arbitrage, dat in beginsel vooral gericht is op financiële genoegdoening. Dit voorstel kwam tot stand in de schoot van een parlementaire commissie die in grote mate bevolkt is door juristen. Het arbitragereglement biedt dan ook een juridisch sterk geformaliseerde procedure, die op papier tot in detail is uitgewerkt. Men heeft zich hierbij niet expliciet laten leiden door 'herstelrechtelijke' principes en evenmin werden meer verregaande formules onderzocht zoals waarheids- en verzoeningscommissies. Zoals in de voorgaande bladzijden moge duidelijk geworden zijn, heeft dit responsmodel vooral een herstelrechtelijke oriëntatie gekregen in de functioneringswijze van de PAK. Hiertoe kreeg de Permanente Arbitragekamer inderdaad alle ruimte: men kon binnen de bestaande contouren van het arbitragereglement een eigen werkwijze uitbouwen die niet in de eerste plaats gericht was op het realiseren van financieel herstel, maar vooral - in de 'verzoeningsfase' - de nadruk legde op het verlenen van een stem aan het slachtoffer, het bieden van erkenning en het faciliteren van een gesprek met de vertegenwoordigers van de kerk, met inbegrip van vragen en ant-

35 Council of Europe Recommendation CM/Rec(2018)8, Rule 3.

36 European Forum for Restorative Justice (2018) Practice Guide on Values and Standards for restorative justice practices, p. 3-4) (www.euforumrj.org/sites/default/files/2019-11/efrj-values-andstandards-manual-to-print-24pp.pdf). 
woorden, toelichting bij de feiten en de complexe gevolgen, respectvol luisteren, discussie over de rol van de kerk, het aanbieden van excuses en ten slotte het mogelijk maken van een - al bij al beperkte en eerder symbolische - financiële tegemoetkoming. De leden van de PAK namen daarbij een actieve, bemiddelende rol op zich, waar ook plaats was voor (doorverwijzing naar) hulpverlening en adviesverlening.

In de werkwijze van de PAK was het bereiken van 'volledig herstel' of 'gerechtigheid' uiteraard geen te realiseren doel van de eenmalige ontmoeting; dit werd ook door niemand beoogd, ook niet door de slachtoffers die doorgaans een grote realiteitszin en redelijkheid aan de dag legden. Wat wél voelbaar was en een verschil maakte met formele procedures, was het klimaat van begrip en erkenning en de oriëntatie op een herstelrechtelijke benadering en dit door een vorm van dialoog. De meeste slachtoffers hadden een dergelijke benadering niet verwacht; ze kwamen naar Brussel in de veronderstelling opnieuw in een soort 'rechtbank' terecht te komen of een confrontatie te moeten aangaan met de kerk.

Waar bovenstaande elementen duidelijk herstelrechtelijke waarden en principes vertolken, valt meteen ook een belangrijke beperking van dit model op: de afwezigheid van de (vermeende) pleger (de geestelijke). In de meeste dossiers was deze persoonlijke aanwezigheid niet mogelijk wegens overlijden of (fysieke of mentale) onbekwaamheid. Toch leeft de indruk dat deze persoonlijke aanwezigheid - in die gevallen waar dit misschien wél mogelijk was geweest - een stap té ver was voor de vertegenwoordigers van de kerk, vooral vanuit een soort ongemak, vrees voor té harde confrontatie of afscherming van de eigen mensen. Andere beperkingen - met het oog op het bereiken van een maximaal herstelrechtelijk gehalte betreffen het feit dat de link met de institutionele oorzaken en implicaties van het misbruik te weinig aan bod kwam en de vrijwel afwezige link met bredere maatschappelijke verbanden. Op deze dimensies komen we hieronder nog terug. In vergelijking met het Centrum voor Arbitrage kan de Vlaamse Commissie Erkenning \& Bemiddeling in haar conceptie veel meer herstelrechtelijk genoemd worden. Het model werd uitgetekend in middens van hulpverleners en bemiddelaars, na voorbereidend werk door gedragsdeskundige experten. Het bieden van erkenning aan slachtoffers als primaire doelstelling verwijst naar een inzicht zoals dat aanwezig is bij ervaren slachtofferhulpverleners. Vandaar ook het aanbod van bemiddeling of doorverwijzing naar lotgenotengroepen, verdere hulpverlening of justitie indien dat aangewezen lijkt. Van financiële tegemoetkoming is geen sprake in het concept, al komt de commissie de facto wel tussen als deze vorm van herstel gewenst en mogelijk is (in de praktijk enkel indien de (vermeende) pleger een geestelijke is). In de uitvoering van dit model werden herstelrechtelijke principes consequent en in detail toegepast, zoals hierboven werd geschetst. Opvallend daarbij is dat - in vergelijking met de PAK - meestal trajecten van langere duur worden gevolgd met de betrokken partijen, op basis van een aanpak op maat. Verder wordt - indien gewenst en mogelijk - ook de (vermeende) pleger in het traject betrokken, ook als het gaat om een priester of religieus. Hoe dan ook is het duidelijk dat de Commissie Erkenning \& Bemiddeling een vrij 'zuiver' herstelrechtelijk model voorstaat, waarbij in de meerderheid van de dossiers ook een 
bemiddeling plaatsvindt met het betrokken instituut of met de (vermeende) pleger, of met beide.

Van beide modellen kan men dus zeggen dat ze - op uiteenlopende wijze - een herstelrechtelijke insteek hanteren. Eén manier om de gehanteerde herstelrechtelijke benadering verder te analyseren, is de confrontatie ervan met algemeen aanvaarde herstelrechtelijke waarden of standaards zoals die in de literatuur beschreven staan. Gekend is de oefening die Braithwaite (2002) maakte om vanuit een filosofisch-republikeinse visie mensenrechtelijke en andere universele normen te verbinden met lokale waarden zoals die in herstelrechtelijke praktijken bottomup verschijnen. Hij maakt daarbij het onderscheid tussen constraining, maximizing en emergent standaards. In de eerste groep van 'dwingende' normen blijken de standaards van non-domination, empowerment, respectful listening, equal concern for all stakeholders en accountability deel uit te maken van beide Belgische responsmodellen, hoewel empowerment en accountability wellicht meer diepgaand en meer omvattend opgevat worden in de commissie dan in de PAK.

De tweede groep van 'maximaliserende' standaards - die aansluiten bij concrete noden van slachtoffers en daders en die zo veel als mogelijk in herstelrechtelijke werkvormen worden toegepast - betreffen vormen van herstel op diverse vlakken: herstel van menselijke waardigheid, eigendomsverlies, veiligheid en gezondheid, menselijke relaties, van gemeenschappen en omgeving, emotioneel herstel, herstel van vrijheid, van mededogen of zorg, van vrede, herstel van het plichtsgevoel als burger, herstel van steun in het verder ontwikkelen van menselijke capaciteiten, en het voorkomen van verder onrecht. In beide hier beschreven responsmodellen zijn niet al deze normen even relevant en zijn ze in wisselende mate aanwezig. Eerder beperkt aanwezig, of althans niet op directe wijze, zijn de normen met betrekking tot het herstel van gemeenschap en vrede. Terwijl de klemtoon bij beide instanties vooral op herstel van de menselijke waardigheid ligt, komen bij de commissie ook emotioneel herstel en in beperkte mate herstel van menselijke relaties aan bod.

De derde groep van standaards - de spontaan tevoorschijn tredende waarden, die men echter niet per definitie mag verwachten in elk herstelrechtelijk proces bevatten uitingen van spijt over het onrecht, verontschuldigingen, afkeuring, vergeving en mildheid. Het is vrij duidelijk dat deze normen sterk op de voorgrond staan in beide Belgische responsmodellen, waar ze - behalve vergeving en mildheid - expliciet een plaats vinden in vrijwel elk dossier en aldus een belangrijke herstelrechtelijke meerwaarde bieden.

Om de beide hier bestudeerde responsmodellen conceptueel nog beter te situeren in het geheel van bestaande herstelrechtelijke werkvormen en opvattingen, kunnen we gebruikmaken van het gekende onderscheid dat Johnstone en Van Ness (2007) maken tussen de encounter, reparative en transformative concepties van het herstelrecht. Het model van de 'ontmoeting' is herkenbaar in beide Belgische responsmodellen, die allebei de nadruk leggen op het bieden van een veilige en ondersteunende omgeving waar - met de hulp van een bemiddelaar - respectvol naar elkaar kan geluisterd worden en gestreefd wordt naar een dialoog over het ervaren onrecht. Toch lijkt dit model wederom in meer doorgedreven vorm en over een langere tijdsspanne aanwezig te zijn in de commissie dan in de PAK. 
Deze laatste bevat, in vergelijking met de commissie, meer elementen van het 'reparatieve' model, wegens de nadruk op het systematisch tot stand brengen van een overeenkomst (of een arbitrage) aangaande een financiële tegemoetkoming. Het zwakst herkenbaar, voor beide responsmodellen, is de 'transformatieve' oriëntatie. Elementen van transformatie kunnen zich wel voordoen op het vlak van de betrokken personen (zelfbeeld) en diepmenselijke relaties, maar veel minder, althans niet op directe wijze, op het vlak van de institutionele of maatschappelijke oorzaken.

Dit laatste brengt ons bij de vraag in welke mate beide modellen succesvol zijn in het verwezenlijken van een 'integrale' herstelbenadering op diverse niveaus.

\subsection{Historisch institutioneel misbruik en geweld: een herstelrechtelijke aanpak op drie niveaus}

\section{- Het individuele niveau (microniveau)}

Bij zowel de PAK als de Commissie Erkenning \& Bemiddeling ligt de klemtoon op het microniveau, dat wil zeggen het niveau van het individuele slachtoffer, eventueel de (vermeende) pleger of een verantwoordelijke van de betrokken instelling. Daarbij staat bij beide instanties het slachtoffer centraal. Deze victim-centered aanpak belet evenwel niet dat beide instanties ook onpartijdig moe(s)ten zijn. Dit werd door de PAK geïnterpreteerd als zich niet eenzijdig identificeren met melder/slachtoffer of instelling. Voor de Commissie Erkenning \& Bemiddeling houdt dit in dat de commissieleden werken volgens het principe van de meerzijdige partijdigheid, waarbij ze geen partij kiezen voor of tegen de ene of andere betrokkene. Daarbij staan de commissieleden open voor een veelheid aan invalshoeken rond eenzelfde gebeuren en trachten ze deze met elkaar te verbinden.

Slachtoffers hebben behoefte aan erkenning: erkenning van het feit dat ze slachtoffer zijn en zelf geen verantwoordelijkheid dragen voor de feiten (wat hun door de (vermeende) pleger vaak is aangepraat), erkenning van het feit dat het geweld of misbruik een onrecht was (en dus niet iets wat 'normaal' was of 'erbij hoorde'), dat het ook dertig of veertig jaar geleden al strafbaar was en dus ook 'naar die tijdsgeest' niet aanvaardbaar was. Ze hebben ook de behoefte om eindelijk geloofd te worden en zijn in die zin dubbel slachtoffer: van de feiten zelf, maar ook van de loodzware cultuur van stilzwijgen, taboe en jarenlang toedekken of minimaliseren van de feiten. Daarbij is ook de erkenning van de verantwoordelijkheid - of zelfs de actieve medeplichtigheid - van de betrokken instelling van groot belang, alsook de erkenning van het falen van de samenleving om het geweld of misbruik te voorkomen of er gepast op te reageren (zie verder onder par. 4.2).

De PAK en de Commissie Erkenning \& Bemiddeling hadden/hebben beide het mandaat om deze erkenning te bieden en beste(ed)den daar veel aandacht aan. Zowel in de PAK als in de commissie staat het onbevooroordeeld beluisteren van het slachtoffer voorop. De waarheid van het slachtoffer wordt niet in vraag gesteld. Dat dit veel betekent voor de slachtoffers, blijkt uit hun reacties: het feit dat het Belgische of Vlaamse Parlement een instantie heeft opgericht die hen ontvangt, actief beluistert en een stem geeft, maakt vaak sterke emoties los en creëert een opening waardoor verdere stappen mogelijk worden. 
Bij de commissie ligt het verdere traject in handen van het slachtoffer en staat een aanpak op maat en volgens de behoeften van het slachtoffer voorop. Bij de PAK was de aanpak meer gestroomlijnd en was er weinig ruimte voor variatie, maar ging er niettemin veel tijd naar het beluisteren van de slachtoffers. Deze aanpak verschilt grondig van de manier waarop in gerechtelijke procedures het woord aan het slachtoffer wordt gegeven.

Meer nog dan de erkenning door de PAK of de commissie is de erkenning door de (vermeende) pleger zelf of door betrokken instelling (zie onder par. 4.2) van groot belang voor het slachtoffer. Wat de (vermeende) pleger betreft heeft de Commissie Erkenning \& Bemiddeling al herhaaldelijk kunnen vaststellen dat deze ook de behoefte kan hebben om zich uit te spreken. Sommigen gaan zelf al jaren gebukt onder het besef van wat ze gedaan hebben en hopen daarvoor ooit hun spijt te mogen uitdrukken ten aanzien van het slachtoffer. Het kan soms een opluchting zijn dat ze door de commissie gecontacteerd worden en de kans krijgen om dit te doen. Dit gebeurt met respect voor de menselijke waardigheid van de (vermeende) pleger. De commissie brengt een dialoog tot stand, waarbij ook contextuele elementen aan bod kunnen komen, maar zal nooit toelaten dat de feiten vergoelijkt of geminimaliseerd worden of dat de (vermeende) pleger zijn verantwoordelijkheid probeert af te wentelen. Daartegenover staan uiteraard ook (vermeende) plegers die de feiten ontkennen, waarbij evenwel ook dezen met respect behandeld worden.

Dat het beluisteren van de (vermeende) pleger door de PAK niet mogelijk was doordat de kerk hen soms afschermde, zoals hierboven beschreven, is daarom betreurenswaardig voor zowel slachtoffer als (vermeende) pleger, ongeacht de motieven van de kerk om dit te doen.

\section{- Het institutionele niveau (mesoniveau)}

Naast erkenning door de PAK of de Commissie Erkenning \& Bemiddeling en indien mogelijk door de (vermeende) pleger, gaat het hier om institutioneel geweld of misbruik, dat wil zeggen geweld of misbruik door een individu gepleegd in de instelling waaraan hij of zij verbonden is als priester, leerkracht, opvoeder, ... doorgaans in het kader van een gezagsrelatie ten aanzien van de minderjarige. Het is precies dit institutionele kader dat misbruik mede mogelijk maakt, in stand houdt en verhult, waardoor ook het effectief optreden sterk bemoeilijkt wordt.

Daarom is ook de erkenning van het onrecht door de verantwoordelijke instelling van belang. De bereidheid van instellingen (het bisdom, de congregatie, scholen, jeugdbewegingen, enz.) om te erkennen dat hun werknemer, medewerker of lid misbruik of geweld heeft gepleegd, is doorgaans aanwezig. Ook dat de instelling destijds niet genoeg heeft gedaan om het te voorkomen of er niet gepast op heeft gereageerd, wordt erkend. Daarbij wordt vaak verwezen naar allerlei inspanningen die inmiddels gedaan zijn om medewerkers te screenen, beter op te leiden en te omkaderen, om incidenten (ook strafrechtelijk) te melden en erop te reageren. Dit is van groot belang voor de slachtoffers, die hierover vaak veel vragen stellen tijdens een bemiddelingsgesprek met de (huidige) verantwoordelijke van de instelling. Ze willen begrijpen hoe het komt dat het misbruik of geweld zoveel jaren heeft kunnen plaatsvinden, vaak door meerdere personen ten aanzien van 
meerdere slachtoffers. Hierin wat inzicht krijgen via een open dialoog kan iets betekenen. Ook is het van groot belang dat de verantwoordelijken van deze instellingen zich excuseren bij de slachtoffers en hun zo mogelijk enige vorm van herstel aanbieden.

Niettemin blijven slachtoffers, en ook de PAK en de commissie, nogal eens op hun honger zitten. Er wordt immers nog al te vaak van uitgegaan dat het louter om het verwerpelijke gedrag van een individu gaat (de 'rotte appel'-theorie). De instanties of instellingen gaan zelden voluit in de erkenning en hun verantwoordelijkheid voor het feit dat ze een omgeving of cultuur hebben gecreëerd en/ of in stand gehouden hebben, waardoor het misbruik of geweld in eerste instantie mogelijk werd en vervolgens jarenlang werd toegedekt, terwijl de (vermeende) plegers niet of nauwelijks ter verantwoording werden geroepen. Dit leidt ertoe dat instituten - zoals in sommige werkvormen de kerk - zelfs menen zich als neutrale bemiddelaar te kunnen positioneren ten overstaan van slachtoffers - terwijl ze zelf betrokken partij zijn. Een zeker paternalisme - diep overtuigd zijn van de eigen kennis en wijsheid omtrent wat goed is voor de medemens - is niet geheel vreemd aan deze werkwijze.

Verschillende factoren - waarop in het kader van deze bijdrage niet verder kan worden ingegaan - dragen bij tot een dergelijke omgeving of cultuur: de ongelijke machtsverhoudingen binnen de instellingen zelf, waardoor de (vaak minderjarige) slachtoffers als het ware aan de onbeperkte en ongecontroleerde macht van de (vermeende) plegers zijn overgeleverd, waarbij de gezinnen van de minderjarigen onderhevig zijn aan beïnvloeding door de instelling, maar waarin ook de (vermeende) plegers vaak zelf in een hiërarchisch verband leven en vaak zonder veel inspraak elders worden ingezet; het maatschappelijke aanzien van de instelling of organisatie, waardoor geruchten over misbruik als ongeloofwaardig en als een aanval op de instelling zelf worden afgedaan; het feit dat deze instellingen of organisaties soms als het ware boven de wet staan en 'conflicten' intern afhandelen; en ten slotte ook het eigenbelang van de instellingen om hun goede reputatie te bewaren en de 'vuile was' niet buiten te hangen. In die zin vormen dergelijke instellingen of organisaties vaak gesloten settings, die - soms op basis van een eigen formeel rechtssysteem zoals het canoniek recht - volgens de eigen regels functioneren, hun eigen normen toepassen en misdrijven als overtredingen van de eigen normen interpreteren waarop men tot voor kort meende alleen maar binnen en volgens het eigen normatieve kader te moeten reageren, zonder externe controle. Alhoewel inmiddels alle actoren wel de tussenkomst van justitie aanvaarden, bestaat deze ingesteldheid nog steeds, niet enkel in gesloten hiërarchische structuren, maar ook in meer 'open' omgevingen, zoals sportorganisaties of de wereld van kunst en cultuur, waar deze normatieve kaders informeler en ongeschreven, maar daarom niet onbestaande zijn.

Dat misbruik en geweld ten aanzien van degenen in een zwakkere positie in een dergelijk kader niet enkel worden mogelijk gemaakt en kunnen floreren, maar er inherent en structureel een onderdeel van vormen, wordt nog onvoldoende erkend en begrepen op institutioneel niveau. Dit laatste neemt niet weg dat binnen deze instellingen bij een aantal individuen een bewustwording op dit vlak groeit en er beperkte beleidsmatige stappen worden gezet. De kerk heeft op dit 
vlak wel degelijk initiatief genomen en aanzetten gegeven tot het ontwikkelen van een coherent beleid (De bisschoppen en hogere oversten van België, 2019). Wellicht is er ook meer wetenschappelijk onderzoek nodig en meer verspreiding van de wetenschappelijke inzichten daarover bij een ruim publiek (zie bijvoorbeeld Keenan, 2013). Opdat de tussenkomt van mechanismen zoals de PAK of de Commissie Erkenning \& Bemiddeling werkelijk zou leiden tot een transformatie, niet enkel van onderliggende relaties maar van de institutionele structuren zelf die tot misbruik leiden, is inderdaad een ruimer maatschappelijk debat nodig.

\section{- Het maatschappelijke niveau (macroniveau)}

Een integrale herstelrechtelijke aanpak om het fenomeen van historisch misbruik te begrijpen en erop te reageren vergt dat niet alleen de persoonlijke en institutionele dimensies onderzocht worden, maar ook het bredere maatschappelijke verband. Institutioneel misbruik is alleen mogelijk in een samenleving die daartoe de culturele en structurele condities levert of die althans faciliteert of tolereert. Houdingen ten aanzien van geweld worden in grote mate mede maatschappelijk gevormd. Het maatschappelijke beeld en meningen over (de positie en noden van) kinderen, hulpbehoevenden of leden van een vereniging, de rol van autoriteit en de invulling van verantwoordelijkheid zijn mede cultureel bepaald en onderhevig aan evoluties in de tijd. Vanuit victimologisch standpunt dienen feiten die zich voordoen in een institutioneel verband - ook al zijn ze, zoals de feiten in kwestie, al strafbaar - op een bepaald ogenblik ook op maatschappelijk niveau gedefinieerd en erkend te worden, bijvoorbeeld als 'slachtofferschap' of vorm van 'onrecht'. Deze maatschappelijke definiëring is noodzakelijk voor de erkenning en perceptie van de feiten van misbruik en geweld op persoonlijk en institutioneel vlak en om vervolgens een maatschappelijke reactie mogelijk te maken.

Adequaat omgaan met de problematiek van historisch institutioneel misbruik en geweld veronderstelt dus het verwerven van inzicht in deze maatschappelijke invloeden bij de totstandkoming of het voortbestaan van dit misbruik en het maatschappelijke definiëringsproces dienaangaande, maar vereist ook een adequaat handelen, met name op een gepaste wijze een beroep doen op maatschappelijke hulpbronnen bij het zoeken naar vormen van duurzaam herstel en een gepaste respons. Welke zijn daarbij de mogelijkheden (geweest) van de twee responsmodellen in België? Qua legitimering hebben zowel de PAK als de Commissie een duidelijke maatschappelijke basis, onder meer omwille van het publieke of politieke karakter van het initiatief dat aan de oorsprong lag van beide responsmodellen. De maatschappelijke dimensie van de problematiek wordt in beide gevallen eveneens expliciet aangenomen in de erkenning van de maatschappelijke laakbaarheid, strafbaarheid en eventuele strafrechtelijke vervolging en veroordeling. Echter, in de herstelrechtelijke methodiek zelf verloopt deze insluiting van de maatschappelijke dimensie minder duidelijk, of veel moeizamer.

De Commissie stelt haar bestaan en optreden voor als 'namens de samenleving'. In de individuele dossiers komt deze maatschappelijke dimensie soms ter sprake zonder evenwel aanleiding te geven tot concrete handelingen naar de samenleving toe. De maatschappelijke dimensie wordt wel gerealiseerd door het expliciet formuleren van beleidsaanbevelingen op basis van de bevindingen in 
individuele dossiers, zoals dat voorzien is in de officiële taakomschrijving van de commissie. In het opzet van het Centrum voor Arbitrage is het maatschappelijke belang eveneens wel degelijk aanwezig, aangezien het zijn bestaansgrond vindt in het voorzien van een afhandeling bij ontstentenis van een strafrechtelijke vervolgingsmogelijkheid (wegens verjaring). Echter, in de doelstellingen en het concrete functioneren van de PAK staat, in vergelijking met de Commissie, de maatschappelijke missie minder op de voorgrond. De maatschappelijke aspecten van de problematiek - opvattingen in de samenleving en bijvoorbeeld de rol van de media waren in sommige gevallen wel voorwerp van gesprek met de slachtoffers en de kerk, maar resulteerden niet in verdere directe actie vanwege de PAK of het Centrum voor Arbitrage. Wel werd via het Wetenschappelijk Comité regelmatig gerapporteerd en verantwoording afgelegd ten aanzien van het federale parlement, waar dan verder actie kan ondernomen worden. Een breed maatschappelijk debat ten gevolge van deze rapportage en over de werking van het Centrum voor Arbitrage in het algemeen heeft echter niet plaatsgevonden. $\mathrm{Na}$ afronding van de werkzaamheden werden de dossiers, bij beslissing van het parlement, overgemaakt aan het Rijksarchief, waar ze met het oog op de bescherming van het privéleven van de slachtoffers, ontoegankelijk zullen zijn voor een periode van dertig jaren. Pas dan kan dit archief ontsloten worden voor wetenschappelijk onderzoek. We herhalen - en betreuren - dat tijdens of na de werking van de PAK geen enkele vorm van wetenschappelijk onderzoek of evaluatie werd doorgevoerd. De weinige mogelijkheden om in de herstelrechtelijke methodiek op directe wijze, in of naar aanleiding van concrete dossiers, de maatschappelijke dimensie te incorporeren, beperkt uiteraard het 'transformatieve' potentieel van deze responsmodellen. Deze beperkte society orientation is echter eigen aan de meeste bestaande werkmodellen in het herstelrecht en vormt dus een enorme uitdaging, zeker wanneer werkvormen als herstelbemiddeling, herstelgericht groepsoverleg (conferencing) of Eigen Kracht-conferenties in concrete dossiers geconfronteerd worden met achterliggende maatschappelijke ongelijkheden, verstoorde machtsevenwichten en vormen van discriminatie. Maar ook meer in het algemeen, zonder het duidelijk op de voorgrond treden van deze maatschappelijke factoren, dient het herstelrecht in zijn werking veel meer de verbinding te maken met de bredere maatschappelijke en culturele context van dominante (en dominerende) waarden en structuren.

\section{Besluit}

In deze bijdrage hebben we een beschrijving en analyse gepresenteerd van het ontstaan en de werking van twee responsmodellen inzake historisch institutioneel misbruik en geweld, zoals die zich in België gedurende de afgelopen jaren hebben ontwikkeld. Het ene model betreft het federale Centrum voor Arbitrage en de werking van de Permanente Arbitragekamer inzake seksueel misbruik in de Kerk, het andere model betreft de Vlaamse Commissie voor Erkenning en Bemiddeling voor institutioneel misbruik en geweld uit het verleden. Deze laatste kent een ruimere werking en richt zich tot allerlei vormen van misbruik en geweld in 
diverse institutionele settings. Onze centrale vraag en tevens rode draad doorheen dit artikel richtte zich op de aanwezigheid, de aard en de kwaliteit van de herstelrechtelijke insteek in beide responsmodellen. Als algemeen antwoord kan geformuleerd worden dat de twee modellen in hun opzet dan wel in hun werking wel degelijk een herstelrechtelijke benadering hanteren. Beide werkvormen delen een aantal gemeenschappelijke herstelrechtelijke waarden en werkingsprincipes, maar kennen ook aanzienlijke verschillen.

Op algemene wijze kan men stellen dat - mede wegens verschillen in opdracht en organisatorisch kader - de herstelrechtelijke benadering op een meer consequente wijze aanwezig is in de Commissie Erkenning \& Bemiddeling dan in de werking van het Centrum voor Arbitrage. Toch kampen beide modellen met een belangrijke beperking, die betrekking heeft op de geringe methodische capaciteit om op basis van de behandeling van individuele dossiers de brug te slaan naar het institutionele en bredere maatschappelijke niveau. Deze - onderling verweven niveaus - dienen integraal betrokken te worden in een herstelrechtelijk antwoord op historisch institutioneel misbruik. Deze analyse, en met name de noodzakelijke oriëntatie op het institutionele en maatschappelijke niveau, lijkt ons relevant voor herstelrechtelijke praktijken in het algemeen. Het is (ook) op dat vlak dat het herstelrecht mogelijk beter kan presteren dan de klassieke strafrechtelijke aanpak, die het actief en daadwerkelijk betrekken van deze diverse niveaus vrijwel geheel verwaarloost door zijn sterk individualiserende benadering van de problematiek.

De toepassing van het herstelrechtelijke gedachtegoed op de problematiek van historisch institutioneel misbruik maakt ook duidelijk hoe determinerend de bestaande opvattingen, waarden en machtsverhoudingen in de samenleving zijn. Herstelrechtelijke methodieken dienen zich fundamenteel en expliciet te richten op de noodzakelijke herdefiniëring en transformatie van maatschappelijke structuren en verhoudingen tussen mensen, en dus opvattingen en vormen van wat 'recht' is en hoe de verschillende niveaus - van micro tot macro - in onderlinge interactie kunnen bijdragen tot de realisatie van het ideaal van een veelzijdige relationele rechtspraxis.

De hier beschreven zoektocht is nog lang niet voltooid. Meer praktijk dient opgebouwd te worden, meer evaluatie- en studiewerk ondernomen te worden tegen de achtergrond van nog andere modellen voor historisch institutioneel misbruik in andere landen. Wellicht dient gezocht te worden naar concepten, mogelijkheden en praktijkvoorbeelden om de diverse functies van modellen te combineren: zowel de maatschappelijke onderzoeksfunctie als de individuele responsfunctie. De formule van (sommige) waarheids- en verzoeningscommissies kan daarbij wellicht inspiratie bieden: het geven van een stem aan kwetsbare personen en miskende groepen, het zoeken naar de grondoorzaken van de problematiek, het maatschappelijk reveleren ervan, het proactief op gang brengen van een maatschappelijk debat, het formuleren van aanbevelingen voor institutionele en maatschappelijke verandering én het faciliteren van individueel herstel en persoonlijke en maatschappelijke heling. 


\section{Literatuur}

Adriaenssens, P. (2010) Verslag activiteiten Commissie voor de behandeling van klachten wegens seksueel misbruik in een pastorale relatie. Leuven: Commissie voor de behandeling van klachten wegens seksueel misbruik in een pastorale relatie.

Braithwaite, J. (2002) Setting Standards for Restorative Justice. British Journal of Criminology, 42, 563-577.

Daly, K. (2014) Redressing institutional abuse of children. New York: Palgrave Macmillan.

De bisschoppen en hogere oversten van België (2019) Seksueel misbruik van minderjarigen in een pastorale relatie in de katholieke Kerk in België. Naar een coherent beleid. Brussel: Stichting Dignity.

Deblauwe, A. (2019) Het belang van erkenning. Naar een permanente Commissie historisch misbruik. Panopticon, 40(2), 136-139.

Devillé, R. (2019) In naam van de vader. Misbruik in de Kerk. Berchem: EPO.

Johnstone, G. \& D.W. Van Ness (2007) The Meaning of Restorative Justice. In: G. Johnstone \& D.W. Van Ness (eds.), Handbook of Restorative Justice (pp. 5-23). Cullompton: Willian Publishing.

Keenan, M. (2013) Child Sexual Abuse and the Catholic Church: Gender, Power, and Organizational Culture. Oxford: Oxford University Press.

Roevens, E. \& I. Aertsen (2014) Kwalitatief onderzoek naar de noden van slachtoffers van historisch geweld en misbruik in jeugd- en onderwijsinstellingen in Vlaanderen. Onderzoek in opdracht van het Departement Welzijn, Volksgezondheid en Gezin van de Vlaamse Overheid. Leuven: Leuvens Instituut voor Criminologie.

Verhoeven, Ph. \& I. Aertsen (2019) Het Centrum voor Arbitrage inzake Seksueel Misbruik: what's in a name? Panopticon, 38(6), 482-491.

Wright, K. (2017) Remaking collective knowledge: an analysis of the complex and multiple effects of inquiries into historical institutional child abuse. Child abuse \& neglect, 74, $10-22$. 